\title{
DESAIN DIDAKTIS PENALARAN MATEMATIS PADA MATA KULIAH KONSEP DASAR MATEMATIKA
}

\author{
Lilis Marina Angraini \\ Pendidikan Matematika, Universitas Islam Riau, Pekanbaru, Indonesia; \\ lilismarina@edu.uir.ac.id
}

\begin{abstract}
The epistemological difficulties of students in mathematical concepts motivate this study. The purpose of this research is to make a didactic design in elementary mathematics subject course. The method is Didactic Design Research. The research was conducted at Riau Islamic University majoring in Primary School Teacher Education in the first semester. The research subjects are 43 students who take the Mathematics Basic Concepts subject for the 2019/2020 school year. Data collection technique is using triangulation, which is a combination of written tests, interviews and documentation studies. Data sources are students, lecturers, and textbooks. The results of this study are didactic designs consisting of three learning designs. The didactic design was developed through three stages. First, compile the initial didactic design based on student difficulties. Second, a metaphorical analysis was carried out during the learning process. Third, retrospectively conducted by comparing the results of the initial obstacle learning test and the results of the final obstacle learning test. This article only discusses the initial didactic design based on student difficulties and the analysis of the tactical methods conducted while learning takes place. The data shows that there are fewer learning difficulties for some students, and others still have learning difficulties. Consequently, a revised didactic design is needed to improve the initial didactic design..
\end{abstract}

Keywords: Didactical design research, Didactic design, Mathematical reasoning, Learning obstacle.

\section{Pendahuluan}

Desain Didaktis merupakan rancangan pembelajaran berupa bahan ajar yang dikembangkan berdasarkan penelitian identifikasi learning obstacle pada proses pembelajaran matematika yang telah muncul sebelumnya. Pada saat proses pembelajaran di kelas, bahan ajar desain didaktis dibuat melalui serangkaian situasi didaktis beserta prediksi respon dan antisipasinya. Desain didaktis dirancang dengan tujuan untuk mengatasi atau mengurangi learning obstacle yang muncul pada pembelajaran sebelumnya, sehingga mahasiswa mampu memahami konsep suatu materi dalam matematika

Euclid, p-ISSN 2355-1712, e-ISSN 2541-4453, Vol. 7, No. 1, pp. 1- 76

CLembaga Penelitian Universitas Swadaya Gunung Jati (UGJ), Cirebon. 
secara utuh. Dengan menggunakan desain didaktis diharapkan learning obstacle yang dialami siswa dapat dikurangi sehingga tujuan pembelajaran matematika dapat tercapai dengan baik.

Menurut Nurwani, dkk (2017) pengembangan desain didaktis mempunyai peranan dalam belajar matematika dan pembelajaran matematika. Peranan tersebut sangat ber-pengaruh terhadap bagaimana mereka melakukan pembelajaran di kelas (Suryadi, 2013). Bahkan pengembangan teori-teori baru diharapkan mampu menjawab hambatan-hambatan pembelajaran, lintasan belajar dan karakteristik mahasiswa. Pengembangan desain didaktis perlu terus dilakukan baik oleh guru, maupun peneliti (Ernasari, 2016).

Menurut Creswell (2014), terdapat dua aspek dasar dalam pembelajaran matematika, yaitu hubungan antara siswa dengan materi dan hubungan antara siswa dengan guru. Hubungan guru dengan siswa disebut pedagogical relation (Hubungan Pedagogis/HP) sedangkan hubungan antara siswa dengan materi disebut dengan didactical relation (Hubungan Didaktis/ HD), yang biasa disajikan dalam segitiga didaktis. Lebih lanjut Creswell (2014) menyatakan bahwa hubungan guru dengan materi tidak dapat diabaikan.

Menurut Suryadi (2016) HD dan HP tidak dapat dipandang secara parsial melainkan dapat terjadi secara bersamaan. Dalam hal ini, guru dapat merancang sebuah situasi didaktis dan membuat prediksi tanggapan siswa serta antisipasinya hingga tercipta situasi yang baru. Dengan demikian, dalam segitiga didaktis perlu ditambahkan hubungan antisipasi antara guru dan siswa, yang disebut dengan ADP (Antisipasi Didaktis Pedagosis). Dalam segitiga didaktis guru berperan untuk menciptakan situasi didaktis (didactical situation) sehingga terjadi proses belajar dalam diri siswa. Hal ini mengindikasikan bahwa guru harus benar-benar menguasai materi ajar, pengetahuan tentang siswa, dan menciptakan situasi didaktis untuk mengoptimalkan pembelajaran. Hal ini selanjutnya dikenal dengan istilah relasi didaktis (didactical relation) (Suryadi, 2011).

Situasi didaktis dan pedagogis merupakan sesuatu yang sangat kompleks, se-hingga guru harus memiliki kemampuan yang dapat memandang hal tersebut secara komprehensif, dapat mengidentifikasi dan menganalisis halhal penting yang terjadi, dan melakukan tindakan yang tepat agar pembelajaran optimal. Kemampuan tersebut selanjutnya disebut sebagai

Euclid, p-ISSN 2355-1712, e-ISSN 2541-4453, Vol. 7, No. 1, pp. $1-76$ (CLembaga Penelitian Universitas Swadaya Gunung Jati (UGJ), Cirebon. 
metapedadidaktik (Suryana, dkk, 2012) (Romdhani \& Suryadi, 2016). Metapedadidaktik terdiri dari tiga komponen penting yaitu kesatuan, fleksibilitas, dan koherensi atau pertalian logis. Kesatuan maksudnya guru mampu memandang sisi-sisi segitiga didaktis yang dimodifikasi sebagai sesuatu yang utuh. Fleksibilitas adalah antisipasi yang sudah disiapkan oleh guru disesuaikan dengan didaktis dan pedagogis. Koherensi maksudnya situasi didaktis yang berkembang pada tiap milieu hingga muncul situasi yang berbeda-beda, maka perbedaan-perbedaan situasi tersebut harus dikelola sehingga perubahan situasi selama proses pembelajaran berjalan dengan lancar dan mengarah dalam pencapaian tujuan (Suryadi, 2013) (Robbia, 2013).

Di dalam didactical design research (DDR), agar pengembangan situasi didaktis, analisis situasi belajar, dan pengambilan keputusan selama proses pembelajaran berlangsung dapat mendorong terjadinya situasi belajar yang optimal diperlukan upaya maksimal yang harus dilakukan sebelum pembelajaran. Upaya tersebut yang dikenal dengan ADP merupakan sintesis hasil pemikiran berdasarkan kemungkinan-kemungkanan yang diprediksikan dapat terjadi dalam proses pembelajaran (Suryadi, 2011). Aspek yang harus dipertimbangkan dalam mengembangkan ADP adalah adanya kesulitan belajar (learning obstacle), terlebih lagi yang bersifat epistemologi (epistemological obstacle). Rohimah (2017) mengemukakan kesulitan belajar adalah suatu gejala yang nampak pada siswa yang ditandai adanya hasil belajar rendah dibanding dengan prestasi yang dicapai sebelumnya. Jadi, kesulitan belajar itu merupakan suatu kondisi dalam proses belajar yang ditandai oleh adanya hambatan-hambatan tertentu dalam mencapai hasil belajar.

Kesulitan belajar disini adalah kesulitan belajar yang biasa dikenal dengan learning obstacle. Learning obstacle ada 3 jenis, yaitu ontogenical learning obstacle, didactical learning obstacle dan epistemological learning obstacle (Yusuf, dkk: 2017) (Safi'i, 2013). Ontogenical learning obstacle adalah kesulitan belajar berdasarkan psikologis, dimana siswa mengalami kesulitan belajar karena faktor kesiapan mental, dalam hal ini cara berfikir siswa yang belum masuk karena faktor usia. Didactical learning obstacle adalah kesulitan belajar siswa terjadi karena kekeliruan penyajian, dalam hal ini bahan ajar yang 
digunakan siswa dalam belajar dapat menimbulkan miskonsepsi. Epistemological learning obstacle adalah kesulitan belajar siswa karena pemahaman siswa tentang sebuah konsep yang tidak lengkap, hanya dilihat dari asal-usulnya saja. Kesulitan belajar yang dialami siswa juga terjadi pada mahasiswa Pendidikan Guru Sekolah Dasar (PGSD) khususnya dalam hal kemampuan penalaran matematis (Marsetyorini \& Murwaningtyas, 2012) (Adiwinata, dkk, 2018).

Kemampuan penalaran matematis merupakan kemampuan mengungkapkan argumen yang sangat esensial untuk memahami matematika (Kahan, 2013). Penalaran matematis merupakan proses yang selalu berlangsung dalam pikiran yang harus dikembangkan secara konsisten dengan menggunakan berbagai macam konteks. Artinya penalaran matematis merupakan kemampuan untuk menganalisis situasi matematis yang berlangsung, kemudian hasil dari proses menganalisis tersebut mencapai sebuah kesimpulan yang konkrit.

Penalaran merupakan proses berpikir yang menghubungkan fakta-fakta yang diketahui menuju kepada suatu kesimpulan (Loc \& Uyen, 2014). Hal ini sejalan dengan apa yang diungkapkan Mofidi, et al (2012), yang menyatakan penalaran sebagai proses penarikan kesimpulan logis berdasarkan fakta dan sumber yang ada. Berdasarkan dua pendapat di atas dapat disimpulkan bahwa kemampuan penalaran diperlukan untuk memperoleh suatu kesimpulan berdasarkan fakta-fakta yang ada sebelum mengambil sebuah keputusan. Priestley (2013) mengungkapkan bahwa matematika merupakan ilmu pengetahuan yang diperoleh melalui bernalar, matematika merupakan pengetahuan tentang bernalar logik serta pengetahuan tentang struktur yang logis. Trouche, et al (2015) menegaskan bahwa asesmen terhadap penalaran matematis yang baik adalah asesmen yang memperhatikan aspek penalaran matematis, diantaranya aktivitas metakognitif yang terlihat ketika (1) meminta siswa memformulasikan strategi untuk menyelesaikan masalah; (2) meminta siswa memonitor serta mengevaluasi penyelesaian. Tujuan penelitian ini adalah: (1) Untuk mengetahui learning obstacle yang terkait dengan kemampuan penalaran matematis mahasiswa pada mata kuliah konsep dasar matematika; (2) Untuk membuat desain didaktis penalaran matematis mahasiswa pada mata kuliah konsep dasar matematika.

Euclid, p-ISSN 2355-1712, e-ISSN 2541-4453, Vol. 7, No. 1, pp. 1- 76 (CLembaga Penelitian Universitas Swadaya Gunung Jati (UGJ), Cirebon. 


\section{Metode}

Penelitian ini dilaksanakan di Universitas Islam Riau jurusan Pendidikan Guru Sekolah Dasar (PGSD) semester I yang mengikuti mata kuliah Konsep Dasar Matematika tahun ajaran 2019/2020 sebanyak 43 orang mahasiswa. Penentuan lokasi penelitian berdasarkan karakteristik yang telah ditentukan oleh peneliti. Sedangkan penentuan kelas yang terpilih sebagai subjek penelitian berdasarkan pertimbangan dosen di tempat penelitian.

Metode yang digunakan dalam penelitian ini adalah Penelitian Desain Didaktis (Didactical Design Research DDR). Menurut Suryadi (2013) DDR memikirkan secara komprehensif tentang apa yang disajikan, bagaimana kemungkinan tanggapan siswa, dan bagaimana mengantisipasinya. Proses berfikir ini dilakukan dalam 3 (tiga) fase pembelajaran, yaitu sebelum pembelajaran, pada saat pembelajaran, dan setelah pembelajaran. Proses berfikir guru pada tiga fase tersebut beserta hasil analisisnya berpotensi untuk menghasilkan desain didaktis inovatif. Penelitian desain didaktis ini terdiri dari tiga tahapan, yaitu: (1) analisis situasi didaktis sebelum pembelajaran yang wujudnya berupa Desain Didaktis Hipotetis termasuk ADP, (2) analisis metapedadidaktik, dan (3) analisis retrosfektif yakni analisis yang mengaitkan hasil analisis situasi didaktis hipotesis dengan hasil analisis metapedadidaktik (Suryadi 2011). Dari ketiga tahapan tersebut akan diperoleh desain didaktis empirik yang tidak tertutup kemungkinan untuk terus disempurnakan melalui tiga tahapan DDR tersebut.

Euclid, p-ISSN 2355-1712, e-ISSN 2541-4453, Vol. 7, No. 1, pp. $1-76$

(CLembaga Penelitian Universitas Swadaya Gunung Jati (UGJ), Cirebon. 


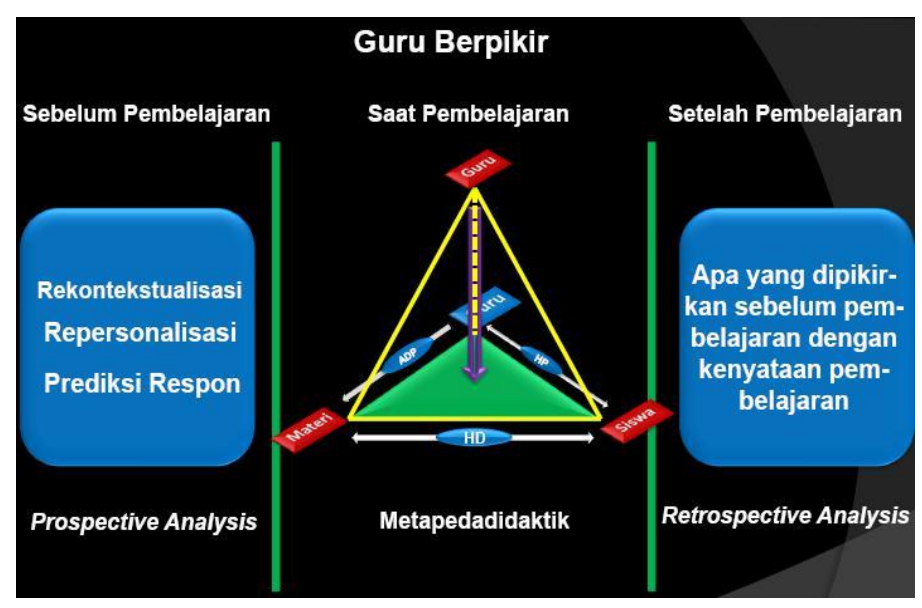

Gambar 1.

Gambar 1. Skema Didactical Design Research (DDR). Sumber: (Suryadi, 2011)

Instrumen dalam penelitian ini terdiri dari instrumen tes penalaran matematis, desain didaktis penalaran matematis, angket, dan lembar observasi. Instrumen tes penalaran matematis pada mata kuliah Konsep Dasar Matematika SD, merupakan instrumen yang sama yang digunakan pada saat studi pendahuluan yang sudah melalui tahap uji validitas, reliabilitas, daya pembeda, dan tingkat kesukaran. Desain didaktis penalaran matematis pada mata kuliah Konsep Dasar Matematika SD, digunakan pada saat uji coba desain didaktis atau implementasi. Instrumen angket berisi tentang tanggapan mahasiswa terkait dengan penggunaan desain didaktis selama pembelajaran. Lembar observasi digunakan untuk mengobservasi aktivitas dosen dan mahasiswa pada saat pembelajaran pada saat uji coba desain didaktis. Teknik pengumpulan data dalam penelitian ini dilakukan dengan triangulasi yaitu gabungan dari tes tertulis, wawancara dan studi dokumentasi, dengan sumber data mahasiswa, dosen dan juga buku ajar.

\section{Hasil dan Pembahasan}

Penyusunan bahan ajar pada umumnya didasarkan pada standar kompetensi dan kompetensi dasar mata kuliah terkait. Materi bahan ajar

Euclid, p-ISSN 2355-1712, e-ISSN 2541-4453, Vol. 7, No. 1, pp. $1-76$ (CLembaga Penelitian Universitas Swadaya Gunung Jati (UGJ), Cirebon. 
yang akan disampaikan juga harus sesuai dengan standar yang ditetapkan. Pada tahap repersonalisasi, peneliti melakukan analisis bahan ajar matematika mahasiswa, yaitu peneliti mengkaji konteks dan konsep materi yang akan diteliti. Sebelum mempersiapkan bahan ajar, seorang dosen perlu memahami konteks materi apa saja dan konsep materi pembelajaran yang nanti akan diajarkan.

Selanjutnya pada tahap rekontektualisasi peneliti mengumpulkan dan menganalis konsepsi mahasiswa mengenai materi ajar yang akan diteliti melalui hasil uji learning obstacle dan hasil wawancara dosen dan mahasiswa. Tipe learning obstacle yang akan diteliti yaitu epistemological obstacle (hambatan epistimologis) kemampuan penalaran matematis mahasiswa pada mata kuliah konsep dasar matematika. Hambatan epistimologis merupakan pengetahuan seseorang yang hanya terbatas pada konteks tertentu karena mahasiswa mengalami lompatan informasi pada pengetahuan yang dimiliki sebelumnya.

Berdasarkan hasil wawancara dan angket tentang kesulitan belajar matematis yang diberikan kepada mahasiswa, diperoleh kesimpulan sebagai berikut: (1) pada umumnya mahasiswa merasa kesulitan belajar matematika dikarenakan matematika terlalu banyak rumus; (2) sulitnya materi-materi matematika menyebabkan mahasiswa menganggap pembelajaran matematika membosankan sehingga mereka cenderung mengabaikan penjelasan guru terkait materi matematika yang dijelaskan; (3) kesulitan yang mereka alami dalam mempelajari materi matematika membuat mereka menyimpulkan bahwa kegunaan matematika dalam kehidupan sehari-hari juga tidak terlalu sering ditemukan; (4) tugas-tugas matematika terlalu banyak dan cenderung lebih sulit dari contoh-contoh soal yang dijelaskan;

Euclid, p-ISSN 2355-1712, e-ISSN 2541-4453, Vol. 7, No. 1, pp. $1-76$ (CLembaga Penelitian Universitas Swadaya Gunung Jati (UGJ), Cirebon. 
(5) mahasiswa menyatakan sering merasa pusing mengerjakan soal-soal matematika terutama soal-soal yang berbentuk cerita.

Desain didaktis ini disusun berdasarkan hasil analisis kesulitan belajar mahasiswa, yaitu identifikasi hambatan dan kesalahan apa saja yang muncul saat mahasiswa menyelesaikan masalah matematika atau saat pembelajaran sebelumnya. Desain didaktis ini terdiri dari beberapa kegiatan dengan materi yang berbeda-beda dengan tujuan sebagai penguatan konsep materi pembelajaran mahasiswa. Berikut akan dijelaskan tentang proses pembelajaran dengan menggunakan desain didaktis yang sudah disusun berdasarkan kesulitan belajar matematis mahasiswa:

Pada LKM-1 mahasiswa diberikan masalah dalam bentuk soal cerita tentang mencari alamat seseorang dengan menggunakan pola bilangan. Berdasarkan masalah tersebut mahasiswa diminta untuk: (1) membuat apa yang diketahui dan ditanya berdasarkan soal; (2) menemukan pola atau sifat dari gejala matematis untuk membuat generalisasi; (3) menentukan manipulasi matematika untuk menyelesaikan masalah; (4) membuat kesimpulan logis dari masalah tersebut. Berikut desain didaktisnya:

\footnotetext{
Masalah 1

Ketika kita mencari alamat rumah seseorang dalam suatu kompleks perumahan. Kita akan melihat pola nomor rumah tersebut, sisi manakah yang genap atau ganjil?, apakah urutan nomor rumahnya semakin bertambah atau berkurang? Dengan memahami pola nomor rumah tersebut kita akan dengan mudah menemukan alamat rumah tersebut tanpa melihat satu persatu nomor rumah yang ada dalam kompleks perumahan tersebut. Suatu hari, Doni ingin berkunjung ke rumah dua orang temannya. Tapi, dia tidak mengetahui berapa nomor rumah kedua temannya. Doni hanya tahu jika rumah temannya yang pertama berada sebelah kiri jalan urutan ke 15 . Sedangkan rumah temannya yang kedua berada di sebelah kanan jalan urutan ke 17. Bagaimana cara Doni mengetahui nomor rumah kedua temannya? Berapakah nomor rumah kedua teman Doni?

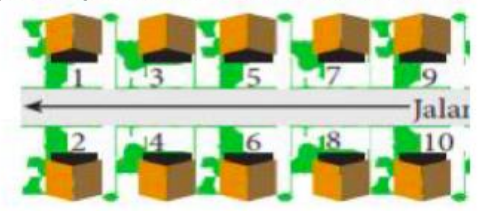

a. Berdasarkan ilustrasi masalah di atas, buatlah apa yang diketahui dan ditanya!

b. Temukan pola atau sifat dari gejala matematis untuk membuat generalisasi!

c. Tentukan manipulasi matematika untuk menyelesaikan masalah di atas!

d. Buatlah kesimpulan logis dari masalah tersebut!
}

Gambar 2. Masalah 1 pada LKM 1

Euclid, p-ISSN 2355-1712, e-ISSN 2541-4453, Vol. 7, No. 1, pp. 1- 76 OLembaga Penelitian Universitas Swadaya Gunung Jati (UGJ), Cirebon. 
Namun sebelum menemukan pola dari permasalahan yang diberikan, mahasiswa diminta untuk memahami tentang barisan pola bilangan, dengan memberikan contoh-contoh soal tentang pola bilangan persegi, pola bilangan persegi panjang, pola bilangan segitiga, pola bilangan kubus, pola bilangan ganjil, pola bilangan genap, dan pola bilangan segitiga pascal.

Setelah menyelesaikan permasalahan 1, mahasiswa diminta untuk mengerjakan soal latihan 1 tentang menyusun kelereng dalam kotak persegi. Berdasarkan masalah tersebut, mahasiswa diminta: (1) membuat apa yang diketahui dan ditanya berdasarkan soal; (2) menemukan pola atau sifat dari gejala matematis untuk membuat generalisasi; (3) menentukan manipulasimatematika untuk menyelesaikan masalah; (4) membuat kesimpulan logis dari masalah tersebut. Berikut desain didaktisnya:

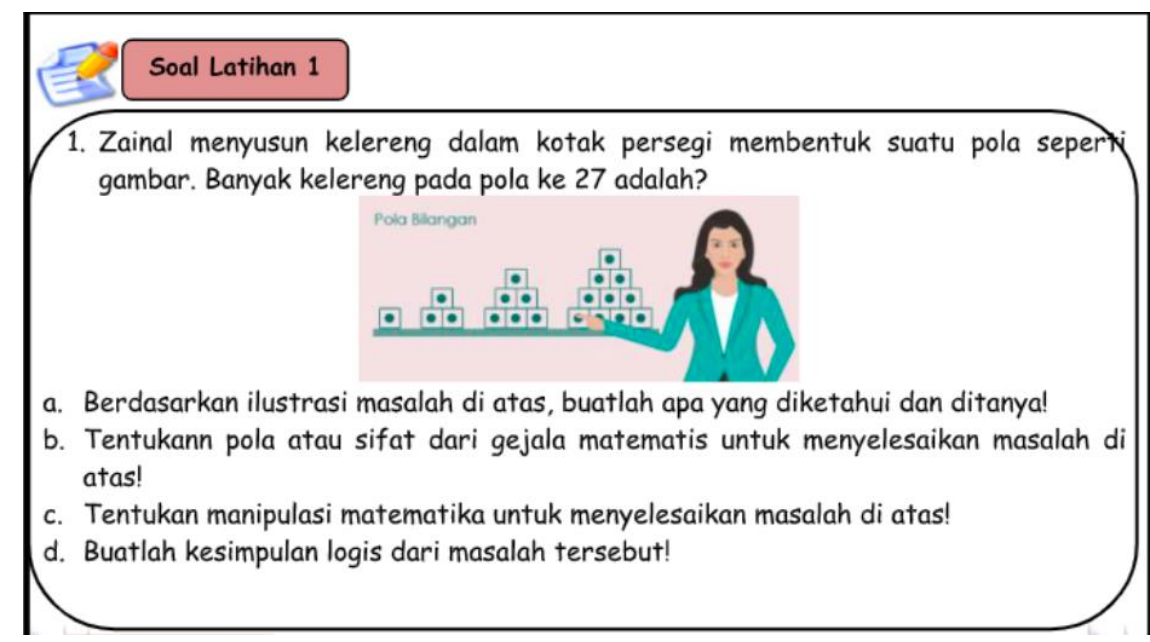

Gambar 3. Soal Latihan 1 pada LKM 1

Setelah menyelesaikan soal latihan 1, mahasiswa diminta untuk mengerjakan soal latihan 2 tentang susunan tumpukan batu bata. Berdasarkan masalah tersebut, mahasiswa diminta: (1) membuat apa yang diketahui dan ditanya berdasarkan soal; (2) menemukan pola atau sifat dari gejala matematis untuk membuat generalisasi; (3) menentukan manipulasi matematika untuk menyelesaikan masalah; (4) membuat kesimpulan logis dari masalah tersebut. Berikut desain didaktisnya: 
Soal Latihan 2

2. Pada tumpukan batu bata, banyak batu bata paling atas ada 20 buah, tepat di bawahnya ada 28 buah, dan seterusnya setiap tumpukan di bawahnya selalu lebih banyak 8 buah dari tumpukan di atasnya. Jika ada 15 tumpukan batu bata (dari atas sampai bawah), banyak batu bata pada tumbukan paling bawah

a. Berdasarkan ilustrasi masalah di atas, buatlah apa yang diketahui dan ditanya!

b. Tentukann pola atau sifat dari gejala matematis untuk menyelesaikan masalah di atas!

c. Tentukan manipulasi matematika untuk menyelesaikan masalah di atas!

d. Buatlah kesimpulan logis dari masalah tersebut!

Gambar 4. Soal Latihan 2 pada LKM 1

Pada LKM-2 mahasiswa diberikan masalah dalam bentuk soal cerita tentang produksi penjualan empek-empek dengan menggunakan pola barisan dan deret aritmetika. Berdasarkan masalah tersebut mahasiswa diminta untuk: (1) membuat apa yang diketahui dan ditanya berdasarkan soal; (2) menemukan pola atau sifat dari gejala matematis untuk membuat generalisasi; (3) menentukan manipulasi matematika untuk menyelesaikan masalah; (4) membuat kesimpulan logis dari masalah tersebut. Berikut desain didaktisnya.

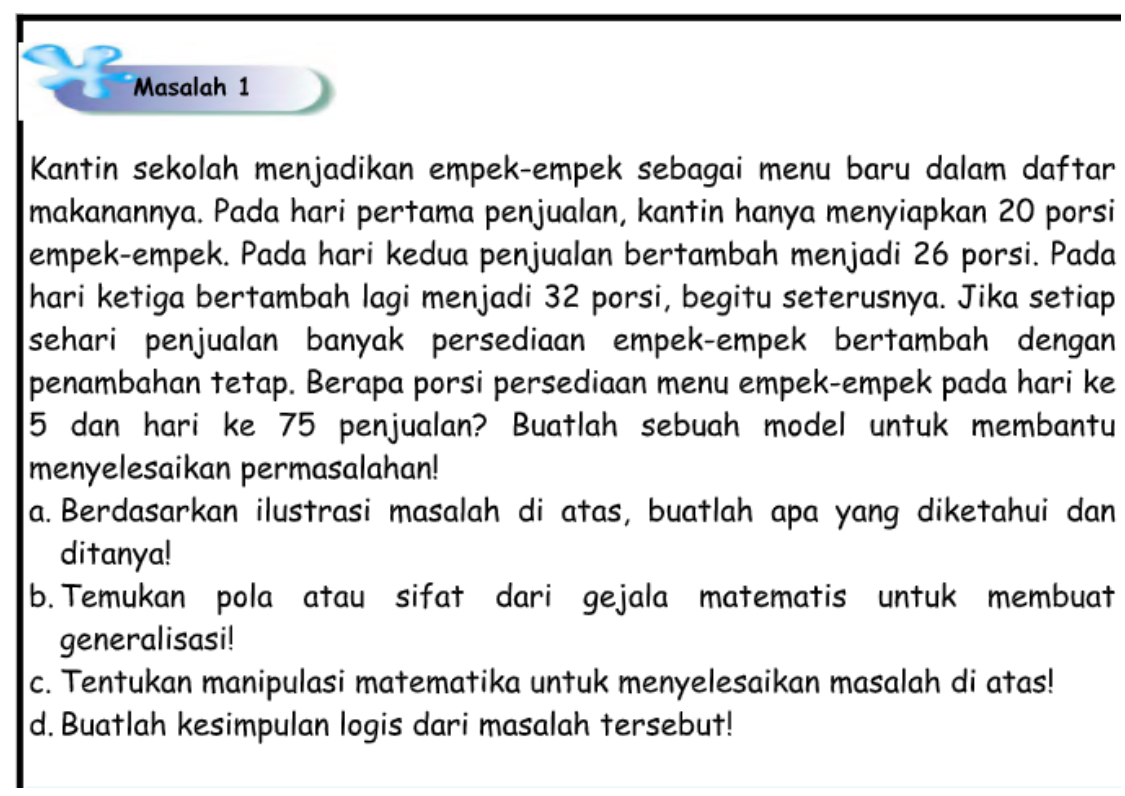

Gambar 5. Masalah 1 pada LKM 2

Euclid, p-ISSN 2355-1712, e-ISSN 2541-4453, Vol. 7, No. 1, pp. $1-76$ (CLembaga Penelitian Universitas Swadaya Gunung Jati (UGJ), Cirebon. 
Namun sebelum menemukan pola dari permasalahan yang diberikan, mahasiswa diminta untuk menemukan rumus dari barisan dan deret aritmetika. Permasalahan tentang penyusunan batu bata merupakan permasalahan yang harus mahasiswa selesaikan untuk menemukan rumus dari barisan dan deret aritmetika.

Setelah menyelesaikan permasalahan 1, mahasiswa diminta untuk mengerjakan soal latihan 1 tentang tentang uang saku mahasiswa di perguruan tinggi. Berdasarkan masalah tersebut, mahasiswa diminta untuk: (1) membuat apa yang diketahui dan ditanya berdasarkan soal; (2) menemukan pola atau sifat dari gejala matematis untuk membuat generalisasi; (3) menentukan manipulasi matematika untuk menyelesaikan masalah; (4) membuat kesimpulan logis dari masalah tersebut. Berikut desain didaktisnya:

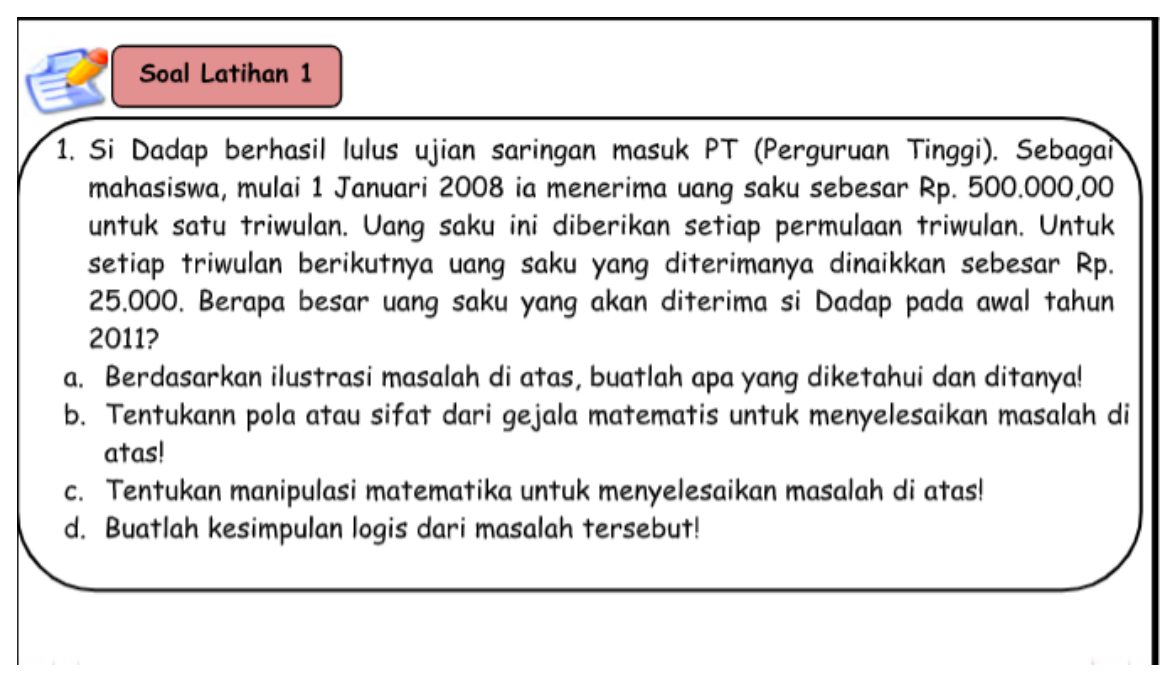

Gambar 6. Soal Latihan 1 pada LKM 2

Setelah menyelesaikan soal latihan 1, mahasiswa diminta untuk mengerjakan soal latihan 2 tentang sebuah perusahaan yang memproduksi mobil mainan. Berdasarkan masalah tersebut, mahasiswa diminta: (1) membuat apa yang diketahui dan ditanya berdasarkan soal; (2) menemukan pola atau sifat dari gejala matematis untuk membuat generalisasi; (3) menentukan manipulasi 
matematika untuk menyelesaikan masalah; (4) membuat kesimpulan logis dari masalah tersebut. Berikut desain didaktisnya:

\section{Soal Latihan 2}

2. Sebuah perusahaan mobil mainan memproduksi 3.000 buah mobil mainan di tahun pertama produksinya. Disebabkan permintaan konsumen yang semakin meningkat, perusahaan memutuskan untuk meningkatkan jumlah produksi sebanyak 300 buah pertahun. Tentukan jumlah mobil mainan yang diproduksi sampai tahun ke 8 !

a. Berdasarkan ilustrasi masalah di atas, buatlah apa yang diketahui dan ditanya!

b. Tentukann pola atau sifat dari gejala matematis untuk menyelesaikan masalah di atas!

c. Tentukan manipulasi matematika untuk menyelesaikan masalah di atas!

d. Buatlah kesimpulan logis dari masalah tersebut!

\section{Gambar 7. Soal Latihan 2 pada LKM 2}

Pada LKM-3 mahasiswa diberikan masalah dalam bentuk soal cerita tentang penyusunan kursi di bioskop dengan menggunakan pola barisan dan deret geometri. Berdasarkan masalah tersebut mahasiswa diminta untuk: (1) membuat apa yang diketahui dan ditanya berdasarkan soal; (2) menemukan pola atau sifat dari gejala matematis untuk membuat generalisasi; (3) menentukan manipulasi matematika untuk menyelesaikan masalah; (4) membuat kesimpulan logis dari masalah tersebut. Berikut desain didaktisnya:

\section{Masalah 1}

Seorang karyawan bioskop akan memasang label pada setiap kursi dalam ruang bioskop. Banyak kursi pada barisan pertama adalah 10, barisan ke dua 20, dan barisan ke tiga 40. Berapa banyak label yang harus disiapkan oleh keryawan bioskop jika dalam satu ruang bioskop terdapat 7 baris kursi?

a. Berdasarkan ilustrasi masalah di atas, buatlah apa yang diketahui dan ditanya!

b. Tentukann pola atau sifat dari gejala matematis untuk menyelesaikan masalah di atas!

c. Tentukan manipulasi matematika untuk menyelesaikan masalah di atas! d. Buatlah kesimpulan logis dari masalah tersebut!

Gambar 8. Masalah 1 pada LKM 3

Euclid, p-ISSN 2355-1712, e-ISSN 2541-4453, Vol. 7, No. 1, pp. 1- 76 (CLembaga Penelitian Universitas Swadaya Gunung Jati (UGJ), Cirebon. 
Namun sebelum menemukan pola dari permasalahan yang diberikan, mahasiswa diminta untuk menemukan rumus dari barisan dan deret geometri. Permasalahan tentang pola bilangan yang mempunyai rasio merupakan permasalahan yang harus mahasiswa selesaikan untuk menemukan rumus dari barisan dan deret geometri.

Setelah menyelesaikan permasalahan 1, mahasiswa diminta untuk mengerjakan soal latihan 1 tentang tentang produksi kerajinan pengusaha. Berdasarkan masalah tersebut, mahasiswa diminta untuk: (1) membuat apa yang diketahui dan ditanya berdasarkan soal; (2) menemukan pola atau sifat dari gejala matematis untuk membuat generalisasi; (3) menentukan manipulasi matematika untuk menyelesaikan masalah; (4) membuat kesimpulan logis dari masalah tersebut. Berikut desain didaktisnya:

Soal Latihan 1

1. Hasil produksi kerajinan seorang pengusaha setiap bulannya meningkat mengikuti aturan deret geometri. Produksi pada bulan pertama sebanyak 150 unit kerajinan dan pada bulan keempat sebanyak 4.050 kerajinan. Carilah hasil produksi unit kerajinan selama 5 bulan?

a. Berdasarkan ilustrasi masalah di atas, buatlah apa yang diketahui dan ditanya!

b. Tentukann pola atau sifat dari gejala matematis untuk menyelesaikan masalah di atas!

c. Tentukan manipulasi matematika untuk menyelesaikan masalah di atas!

d. Buatlah kesimpulan logis dari masalah tersebut!

\section{Gambar 9. Soal Latihan 1 pada LKM 3}

Setelah menyelesaikan soal latihan 1, mahasiswa diminta untuk mengerjakan soal latihan 2 tentang kejuaraan basket tingkat nasional. Berdasarkan masalah tersebut, mahasiswa diminta: (1) membuat apa yang diketahui dan ditanya berdasarkan soal; (2) menemukan pola atau sifat dari gejala matematis untuk membuat generalisasi; (3) menentukan manipulasi matematika untuk menyelesaikan masalah; (4) membuat kesimpulan logis dari masalah tersebut. Berikut desain didaktisnya:

Euclid, p-ISSN 2355-1712, e-ISSN 2541-4453, Vol. 7, No. 1, pp. $1-76$

(CLembaga Penelitian Universitas Swadaya Gunung Jati (UGJ), Cirebon. 
Soal Latihan 2

2. Dalam kejuaraan basket tingkat nasional putaran pertama diikuti oleh 128 team. Putaran kedua diikuti oleh 64 team dan putaran berikutnya 32 team, 16 team dan seterusnya. Tuliskan aturan untuk menjelaskan barisan bilangan tersebut dan carilah tiga suku berikutnya!

a. Berdasarkan ilustrasi malsalah di atas, buatlah apa yang diketahui dan ditanya!

b. Tentukann pola atau sifat dari gejala matematis untuk menyelesaikan masalah di atas!

c. Tentukan manipulasi matematika untuk menyelesaikan masalah di atas!

d. Buatlah kesimpulan logis dari masalah tersebut!

\section{Gambar 10. Soal Latihan 2 pada LKM 3}

Sebelum desain didaktis ini diimplementasikan, terlebih dahulu dibuat prediksi berbagai respon mahasiswa yang akan muncul beserta antisipasiantisipasi didaktisnya. Setelah desain didaktis diimplementasikan pada proses pembelajaran, ternyata sebagian besar respon mahasiswa sesuai dengan prediksi yang telah dibuat sebelumnya, ada pula prediksi respon mahasiswa yang tidak muncul dan terdapat juga respon mahasiswa dengan kesulitan baru yang muncul. Pada LKM-1 mahasiswa diberikan masalah dalam bentuk soal cerita tentang mencari alamat seseorang dengan menggunakan pola bilangan. Berdasarkan masalah tersebut mahasiswa diminta untuk: (1) membuat apa yang diketahui dan ditanya berdasarkan soal; (2) menemukan pola atau sifat dari gejala matematis untuk membuat generalisasi; (3) menentukan manipulasi matematika untuk menyelesaikan masalah; (4) membuat kesimpulan logis dari masalah tersebut.

Pada poin membuat apa yang diketahui dan apa yang ditanya berdasarkan soal, tidak ada hambatan bagi mahasiswa, semua bisa melakukan dengan baik. Namun sebelum menemukan pola dari permasalahan yang diberikan, mahasiswa diminta untuk memahami tentang barisan pola bilangan, dengan memberikan contoh-contoh soal tentang pola bilangan persegi, pola bilangan persegi panjang, pola bilangan segitiga, pola bilangan kubus, pola bilangan ganjil, pola bilangan genap, dan pola bilangan segitiga pascal.

Euclid, p-ISSN 2355-1712, e-ISSN 2541-4453, Vol. 7, No. 1, pp. 1- 76 CLembaga Penelitian Universitas Swadaya Gunung Jati (UGJ), Cirebon. 
Selama menentukan pola bilangan persegi, pola bilangan persegi panjang, pola bilangan segitiga, pola bilangan kubus, pola bilangan ganjil, pola bilangan genap, dan pola bilangan segitiga pascal tidak ada hambatan yang terjadi, namun saat menjawab pertanyaan kedua dari permasalahan yang diberikan, yaitu tentang menemukan pola atau sifat dari gejala matematis untuk membuat generalisasi, mahasiswa tidak bisa menentukan dengan tepat, proses penalaran yang mereka bangun kurang tepat, mahasiswa menjawab jalan urutan ke-15 sebagai bilangan genap dan jalan urutan ke-17 sebagai bilangan ganjil, dengan demikian mereka juga salah dalam menentukan manipulasi matematika untuk menyelesaikan masalah.

Berdasarkan pengamatan, mahasiswa kurang teliti dalam memahami persoalan tentang penalaran matematis pada LKM-1 poin masalah 1. Proses penalaran matematis yang dilakukan mahasiswa perlu dilakukan bantuanbantuan baik secara langsung ataupun tidak langsung agar mereka mampu menyelesaikan permasalahan 1 dengan baik.

Setelah menyelesaikan permasalahan 1 dengan baik, mahasiswa diminta untuk mengerjakan soal latihan 1 tentang menyusun kelereng dalam kotak persegi. Berdasarkan masalah tersebut, mahasiswa diminta: (1) membuat apa yang diketahui dan ditanya berdasarkan soal; (2) menemukan pola atau sifat dari gejala matematis untuk membuat generalisasi; (3) menentukan manipulasi matematika untuk menyelesaikan masalah; (4) membuat kesimpulan logis dari masalah tersebut. Semua pertanyaan dalam soal latihan 1 mampu terselesaikan dengan baik, artinya proses penalaran yang mereka bangun berdasarkan permasalahan yang diberikan sudah berhasil.

Setelah menyelesaikan soal latihan 1 dengan baik, mahasiswa diminta untuk mengerjakan soal latihan 2 tentang susunan tumpukan batu bata. Berdasarkan masalah tersebut, mahasiswa diminta: (1) membuat apa yang 
diketahui dan ditanya berdasarkan soal; (2) menemukan pola atau sifat dari gejala matematis untuk membuat generalisasi; (3) menentukan manipulasi matematika untuk menyelesaikan masalah; (4) membuat kesimpulan logis dari masalah tersebut. Semua pertanyaan dalam soal latihan 2 mampu terselesaikan dengan baik, artinya proses penalaran yang mereka bangun berdasarkan permasalahan yang diberikan sudah berhasil. Dengan demikian dapat disimpulkan proses penalaran pada matei pola bilangan dengan menggunakan desain didaktis yang sudah disusun berdasarkan kesulitan belajar matematis mahasiswa sudah cukup efektif.

Pada LKM-2 mahasiswa diberikan masalah dalam bentuk soal cerita tentang produksi penjualan empek-empek dengan menggunakan pola barisan dan deret aritmetika. Berdasarkan masalah tersebut mahasiswa diminta untuk: (1) membuat apa yang diketahui dan ditanya berdasarkan soal; (2) menemukan pola atau sifat dari gejala matematis untuk membuat generalisasi; (3) menentukan manipulasi matematika untuk menyelesaikan masalah; (4) membuat kesimpulan logis dari masalah tersebut.

Pada poin membuat apa yang diketahui dan apa yang ditanya berdasarkan soal, tidak ada hambatan bagi mahasiswa, semua bisa melakukan dengan baik. Namun sebelum menemukan pola dari permasalahan yang diberikan, mahasiswa diminta untuk menemukan rumus dari barisan dan deret aritmetika. Permasalahan tentang penyusunan batu bata merupakan permasalahan yang harus mahasiswa selesaikan untuk menemukan rumus dari barisan dan deret aritmetika.

Selama menyelesaikan permasalahan tentang penyusunan batu bata, agar mahasiswa dapat menemukan rumus dari barisan dan deret aritmetika tidak mengalami kendala yang berarti, sehingga saat menjawab pertanyaan kedua dari permasalahan yang diberikan, yaitu tentang menemukan pola atau sifat

Euclid, p-ISSN 2355-1712, e-ISSN 2541-4453, Vol. 7, No. 1, pp. $1-76$ (CLembaga Penelitian Universitas Swadaya Gunung Jati (UGJ), Cirebon. 
dari gejala matematis untuk membuat generalisasi, mahasiswa bisa menentukan dengan tepat, proses penalaran yang mereka bangun tepat, mahasiswa juga bisa menentukan manipulasi matematika untuk menyelesaikan masalah, dan membuat kesimpulan logis dari masalah tersebut.

Setelah menyelesaikan permasalahan 1 dengan baik, mahasiswa diminta untuk mengerjakan soal latihan 1 tentang tentang uang saku mahasiswa di perguruan tinggi. Berdasarkan masalah tersebut, mahasiswa diminta untuk: (1) membuat apa yang diketahui dan ditanya berdasarkan soal; (2) menemukan pola atau sifat dari gejala matematis untuk membuat generalisasi; (3) menentukan manipulasi matematika untuk menyelesaikan masalah; (4) membuat kesimpulan logis dari masalah tersebut. Pertanyaan dalam soal latihan 1 poin (1) dan (3) mampu terselesaikan dengan baik, artinya proses penalaran yang mereka bangun berdasarkan permasalahan yang diberikan sudah berhasil. Namun, pertanyaan dalam soal latihan 1 poin (2) dan (4) tidak diselesaikan (tidak dijawab), mahasiswa kurang teliti mengerjakan jawaban dari pertanyaan-pertanyaan yang diberikan, hal ini disebabkan oleh ketidakhati-hatian dalam membaca soal dan memaknai setiap pertanyaan-pertnyaan yang diberikan, serta kemampuan penalaran dalam mengamati soal mereka belum cukup baik.

Setelah menyelesaikan soal latihan 1, mahasiswa diminta untuk mengerjakan soal latihan 2 tentang sebuah perusahaan yang memproduksi mobil mainan. Berdasarkan masalah tersebut, mahasiswa diminta: (1) membuat apa yang diketahui dan ditanya berdasarkan soal; (2) menemukan pola atau sifat dari gejala matematis untuk membuat generalisasi; (3) menentukan manipulasi matematika untuk menyelesaikan masalah; (4) membuat kesimpulan logis dari masalah tersebut. Pertanyaan dalam soal latihan 2 poin (1) mampu 
terselesaikan dengan baik, artinya proses penalaran yang mereka bangun berdasarkan permasalahan yang diberikan sudah berhasil. Namun pertanyaan dalam soal latihan 1 poin (2), (3) dan (4) tidak diselesaikan (tidak dijawab), mahasiswa kurang teliti mengerjakan jawaban dari pertanyaanpertanyaan yang diberikan, hal ini disebabkan oleh ketidakhati-hatian dalam membaca soal dan memaknai setiap pertanyaan-pertnyaan yang diberikan, serta kemampuan penalaran dalam mengamati soal mereka belum cukup baik.

Pada LKM-3 mahasiswa diberikan masalah dalam bentuk soal cerita tentang penyusunan kursi di bioskop dengan menggunakan pola barisan dan deret geometri. Berdasarkan masalah tersebut mahasiswa diminta untuk: (1) membuat apa yang diketahui dan ditanya berdasarkan soal; (2) menemukan pola atau sifat dari gejala matematis untuk membuat generalisasi; (3) menentukan manipulasi matematika untuk menyelesaikan masalah; (4) membuat kesimpulan logis dari masalah tersebut.

Pada poin membuat apa yang diketahui dan apa yang ditanya berdasarkan soal, tidak ada hambatan bagi mahasiswa, semua bisa melakukan dengan baik. Namun sebelum menemukan pola dari permasalahan yang diberikan, mahasiswa diminta untuk menemukan rumus dari barisan dan deret geometri. Permasalahan tentang pola bilangan yang mempunyai rasio merupakan permasalahan yang harus mahasiswa selesaikan untuk menemukan rumus dari barisan dan deret geometri.

Selama menyelesaikan permasalahan tentang pola bilangan yang mempunyai rasio, guna menemukan rumus dari barisan dan deret geometri, mahasiswa tidak mengalami kendala yang berarti, sehingga saat menjawab pertanyaan kedua dari permasalahan yang diberikan, yaitu tentang menemukan pola atau sifat dari gejala matematis untuk membuat

Euclid, p-ISSN 2355-1712, e-ISSN 2541-4453, Vol. 7, No. 1, pp. $1-76$ (CLembaga Penelitian Universitas Swadaya Gunung Jati (UGJ), Cirebon. 
generalisasi, mahasiswa bisa menentukan dengan tepat, proses penalaran yang mereka bangun tepat, mahasiswa juga bisa menentukan manipulasi matematika untuk menyelesaikan masalah, dan membuat kesimpulan logis dari masalah tersebut.

Setelah menyelesaikan permasalahan 1, mahasiswa diminta untuk mengerjakan soal latihan 1 tentang tentang produksi kerajinan pengusaha. Berdasarkan masalah tersebut, mahasiswa diminta untuk: (1) membuat apa yang diketahui dan ditanya berdasarkan soal; (2) menemukan pola atau sifat dari gejala matematis untuk membuat generalisasi; (3) menentukan manipulasi matematika untuk menyelesaikan masalah; (4) membuat kesimpulan logis dari masalah tersebut. Pertanyaan dalam soal latihan 1 poin (1), (2), (3) dan (4) mampu terselesaikan dengan baik, artinya proses penalaran yang mereka bangun berdasarkan permasalahan yang diberikan sudah berhasil.

Setelah menyelesaikan soal latihan 1, mahasiswa diminta untuk mengerjakan soal latihan 2 tentang kejuaraan basket tingkat nasional. Berdasarkan masalah tersebut, mahasiswa diminta: (1) membuat apa yang diketahui dan ditanya berdasarkan soal; (2) menemukan pola atau sifat dari gejala matematis untuk membuat generalisasi; (3) menentukan manipulasi matematika untuk menyelesaikan masalah; (4) membuat kesimpulan logis dari masalah tersebut. Pertanyaan dalam soal latihan 2 poin (1) dan (2) mampu terselesaikan dengan baik, artinya proses penalaran yang mereka bangun berdasarkan permasalahan yang diberikan sudah berhasil. Namun pertanyaan dalam soal latihan 2 poin (3) dan (4) tidak diselesaikan dengan baik, mahasiswa kurang teliti mengerjakan jawaban dari pertanyaanpertanyaan yang diberikan, hal ini disebabkan oleh ketidakhati-hatian dalam membaca soal dan memaknai setiap pertanyaan-pertanyaan yang diberikan, 
serta kemampuan penalaran dalam mengamati soal mereka belum cukup baik.

\section{Kesimpulan}

Berdasarkan analisis dari hasil penelitian dan pembahasannya, maka dapat ditarik kesimpulan sebagai berikut: Learning obstacle yang teridentifikasi terkait kemampuan penalaran matematis mahasiswa pada mata kuliah konsep dasar matematika adalah: (a) Learning obstacle terkait konsep pola bilangan, barisan dan deret aritmetika, serta barisan dan deret geometri; (b) Learning obstacle terkait dengan menyelesaikan soal kemampuan penalaran matematis mahasiswa; (c) Learning obstacle terkait dengan konsep materi matematika lain.

Learning obstacle yang bersifat epistimologis yang teridentifikasi pada penelitian ini diantaranya sebagai berikut: (a) Kesulitan mahasiswa dalam belajar matematika dikarenakan matematika terlalu banyak rumus; (b) Kesulitan terkait koneksi konsep pola bilangan, barisan dan deret aritmetika, serta barisan dan deret geometri; (c) Kesulitan memahami soal cerita; (d) Kesulitan menganalisis perbedaan soal-soal pola bilangan, barisan dan deret aritmetika, serta barisan dan deret geometri; (e) Kesulitan terkait koneksi konsep materi dengan konsep matematika lain.

Desain didaktis yang dikembangkan adalah berupa desain pembelajaran yang dilengkapi dengan LKM (Lembar Kerja Mahasiswa) yang disusun berdasarkan hasil identifikasi kesulitan mahasiswa saat uji learning obstacle awal dan teori belajar yang relevan. Hasil implementasi desain didaktis konsep penalaran matematis mahasiswa sesuai dengan prediksi respon yang dibuat, adapun respon mahasiswa yang tidak terprediksi diantisipasi dengan solusi yang diambil saat pembelajaran berlangsung.

Euclid, p-ISSN 2355-1712, e-ISSN 2541-4453, Vol. 7, No. 1, pp. $1-76$ (CLembaga Penelitian Universitas Swadaya Gunung Jati (UGJ), Cirebon. 


\section{Daftar Pustaka}

Adiwinata, dkk. (2018). Learning Obstacle untuk Siswa SMP Materi Tabung dan Kerucut. Prosiding Seminar Nasional Matematika dan Pendidikan Matematika. UIN Raden Intan Lampung.

Creswell, W. J. (2014). Research Desain (Pendekatan Kualitatif, Kuantitatif, dan Mix). Jogyakarta: Pustaka Pelajar.

Ernasari, T. (2016). Desain Didaktis Materi Jenis dan Besar Sudut Berdasarkan Analisis Learning Obstacle Pada Buku Paket Teks Matematika Kelas III Sekolah Dasar di Kota Serang. Artikel Universitas Pendidikan Indonesia. Vol. 4.

Kahan, D.M. (2013). Ideology, motivated reasoning, and cognitive reflection. Judgment and Decision Making. Vol. 8, No. 4, pp. 407-424.

Loc \& Uyen. (2014). Using analogy in teaching mathematics: an investigation of mathematics education students in school of education - Can Tho University. International Journal of Education and Research. Vol. 2 No. 7.

Mofidi, et al. (2012). Instruction of mathematical concepts through analogical reasoning skills. Indian Journal of Science and Technology. Vol. 5 No. 6.

Marsetyorini, A. D. \& Murwaningtyas. (2012). Diagnosis Kesulitan Belajar Siswa Dan Pembelajaran Remedial Dalam Materi Operasi Pada Pecahan Bentuk Aljabar Di Kelas VIII SMPN 2 Jetis Bantul. Jurnal Ilmu Pendidikan. (Online), (http://ejurnal.fkip.usd.ac.id, diakses 15 Januari 2016).

Nurwani, dkk. (2017). Pengembangan Desain Didaktis Bahan Ajar Materi Pemfaktoran Bentuk Aljabar pada Pembelajaran Matematika SMP. Numerical: Jurnal Matematika Dan Pendidikan Matematika. 1(2), 193-206.

Priestley, M. (2013). Wandering about: analogy, ambiguity and humanistic mathematics. Journal of Humanistic Mathematics. Vol.3 Issue 1.

Robbia, D. (2013). Desain Didaktis Model Problem Solving Untuk Mengatasi Learning Obstacle Pokok Bahasan Teorema Phytagoras pada Pembelajaran Matematika Untuk Meningkatkan Kompetensi Matematis SMP. Jurnal Ilmu Pendidikan. (Online), (http://ejurnal.fkip.upi.ac.id, diakses 9 Januari 2016).

Rohimah, S. M. (2017). Analisis Learning Obstacles pada Materi Persamaan dan Pertidaksamaan Linier Satu Variabel. Jurnal JPPM. 10(1), 132-141.

Euclid, p-ISSN 2355-1712, e-ISSN 2541-4453, Vol. 7, No. 1, pp. $1-76$

(CLembaga Penelitian Universitas Swadaya Gunung Jati (UGJ), Cirebon. 
Retrieved

from

https://jurnal.untirta.ac.id/index.php/IPPM/article/download/1293/103

6.

Romdhani, W. \& Suryadi, D. (2016). Desain Didaktis Konsep Pecahan untuk Kelas III Sekolah Dasar. Edu Humaniora: Jurnal Pendidikan Dasar. Vol. 8. No.2. Hal 198-210.

Suryadi, D. (2011). Didactical Design Research (DDR) Dalam Pengembangan Pembelajaran Matematika 1. Jurnal Ilmu Pendidikan. (Online). (http://ejurnal.fkip.upi.ac.id, diakses 15 Februari 2016).

Suryadi, D. (2011). Kesetaraan Didactical Design Research (DDR) Dengan Matematika Realistik Dalam Pengembangan Pembelajaran Matematika. Makalah pada Seminar Nasional Matematika dan Pendidikan Matematika. UNS.

Suryadi, D. (2013). Didactical design research (DDR) dalam pengembangan pembelajaran matematika. In Prosiding Seminar Nasional Matematika dan Pendidikan Matematika (pp. 3-12).

Suryadi, D. (2016). Didactical Design Research (DDR): Upaya membangun kemandirian Berpikir Melalui Penelitian Pembelajaran. Makalah pada Seminar Nasional Matematika dan Pendidikan Matematika. UNSWAGATI.

Suryana, dkk. (2012). Desain Didaktis Pengenalan Konsep Pecahan Sederhana Pada Pembelajaran Matematika Untuk Siswa Kelas III Sekolah Dasar. Jurnal Ilmu Pendidikan. (Online), (http://ejurnal.fkip.upi.ac.id, diakses 15 Februari 2016).

Safi'i, I. (2013). Diagnosis Kesalahan Siswa pada Faktorisasi Bentuk Aljabar dan Scaffoldingnya. Jurnal Ilmu Pendidikan. (Online), (http://ejurnal.fkip.unm.ac.id, diakses 15 Januari 2016).

Trouche, et al. (2015). The selective laziness of reasoning. Cognitive Science, 1-15. ISSN: 0364-0213 print / 1551-6709 online.

Yusuf, dkk. (2017). Analisis Hambatan Belajar ( Learning Obstacle ) Siswa SMP pada Materi Statistika. Jurnal Aksioma. 8(1), 76-86.

Euclid, p-ISSN 2355-1712, e-ISSN 2541-4453, Vol. 7, No. 1, pp. 1- 76 (CLembaga Penelitian Universitas Swadaya Gunung Jati (UGJ), Cirebon. 